\title{
DEVELOPMENT OF AN OPERATIONAL ELBE TIDAL ESTUARY MODEL
}

\author{
Sylvin H. Müller-Navarra and Ingrid Bork ${ }^{1}$
}

\begin{abstract}
Due to local tidal conditions, vessels coming in from the North Sea and bound for the port of Hamburg - more than $100 \mathrm{~km}$ upstream - require continually updated hydrological and oceanographic forecasts. The principal objective of the research project OPTEL (Operational Elbe Tidal Estuary Model) is to provide hydrological and oceanographic forecasts about water levels, depths, currents, salinity, temperature and ice conditions for any tidally influenced place on the river Elbe. By using a numerical model, it is ensured that water levels and currents are coupled dynamically, which allows peak water levels, slack water times, and - in 3D modelling - flow profile to be modelled in a physically consistent way and with high resemblance to natural conditions. The model concept including model output statistics (MOS) and first model results are presented.
\end{abstract}

Keywords: tidal river Elbe; numerical model; water level forecasts; model output statistics (MOS)

\section{INTRODUCTION}

The river Elbe, especially the Lower Elbe with its tidal influence, is a very busy shipping route. Due to local tidal conditions, vessels coming in from the North Sea and bound for the port of Hamburg require continually updated information about water levels and depths. Certain navigational manoeuvres in the port of Hamburg (e.g. docking, turning of very large ships) additionally require thorough knowledge of the tide-influenced current conditions in the river Elbe. The port of Hamburg, located about $130 \mathrm{~km}$ upstream from the river mouth, is the largest German seaport and ranks among the 20 top harbours worldwide. The Elbe waterway is one of the most important and busiest fairways in Europe. Besides the dimensions of a fairway, also its safety and navigation aspects are important for port accessibility. Navigation on the river Elbe is very dependent on water levels, which are influenced by the tides and by wind set-up. In the harbour area of Hamburg, the difference between the highest water level ever recorded and the absolutely lowest level on record is almost 10 metres. The mean tidal range is $3.6 \mathrm{~m}$. During severe storm surges, the river level may rise by more than $3.5 \mathrm{~m}$. Between the estuary mouth and a weir - $160 \mathrm{~km}$ upstream - at Geesthacht, the flood period decreases considerably, and the ebb period decreases accordingly.

The North Sea is part of the North West European shelf sea. The coastline of the North Sea touches UK, France, Belgium, The Netherlands, Germany, Danmark and Norway. The estuary of the River Elbe is located in the south-eastern corner of the German Bight. The main feature of the inner German Bight is its flatness. In large areas of the German Bight the water is less than $10 \mathrm{~m}$ deep. As a consequence, water levels in the lower Elbe river are strongly influenced by wind set-up.

The river Elbe, which is more than $1,000 \mathrm{~km}$ long, has a catchment area of about $148,000 \mathrm{~km}^{2}$. Mean river run-off at the upper open boundary of the Elbe is about $500-700 \mathrm{~m}^{3} / \mathrm{s}$, an extreme value of $3,500 \mathrm{~m}^{3} / \mathrm{s}$ was reached in August 2006.

Natural erosion and sedimentation processes are taking place continuously in this highly dynamic system. Major changes have been observed in the past several decades, especially near the river mouth. The natural development of the estuary has been altered by anthropogenic measures such as land reclamation, dyking, dredging and other hydraulic engineering measures. All of these measures have had noticeable impacts on the characteristic landscape and on the dynamics and hydro-morphological situation of the river. River depth is continuously recorded.

The fairway depth profile between the mouth of the river Elbe and a point $150 \mathrm{~km}$ upriver is shown in Fig. 1. Water depth varies between $30 \mathrm{~m}$ and $10 \mathrm{~m}$ upriver of the Hamburg harbour area. The profile shows clearly that a minimum depth of $13.5 \mathrm{~m}$ is maintained as far as the harbour of Hamburg, and that the seabed level upriver is markedly higher. At the weir of Geesthacht, locks are operated for shipping. The purpose of the weir at Geesthacht is to ensure that the water level upriver is sufficient for inland navigation. In case of major flood runoff or high storm surge levels propagating inland, the water level at the weir is reduced by up to $2.5 \mathrm{~m}$ from the normal level of $4 \mathrm{~m}$. Upriver of the weir, the riverbed is above MSL. Therefore, a water level corresponding to mean water level (MWL) must be chosen as initial condition for the model. In this way, the water depth related to mean water level (MWL) is obtained.

\footnotetext{
${ }^{1}$ Federal Maritime and Hydrographic Agency, Bernhard-Nocht-Straße 78, D-20249 Hamburg, Germany
} 
In severe winter seasons, the river Elbe is covered with ice floes. Upriver of Hamburg, in shallower water, rafting of ice floes may cause considerable ice jams which have to be broken by icebreakers in order to avoid flooding.

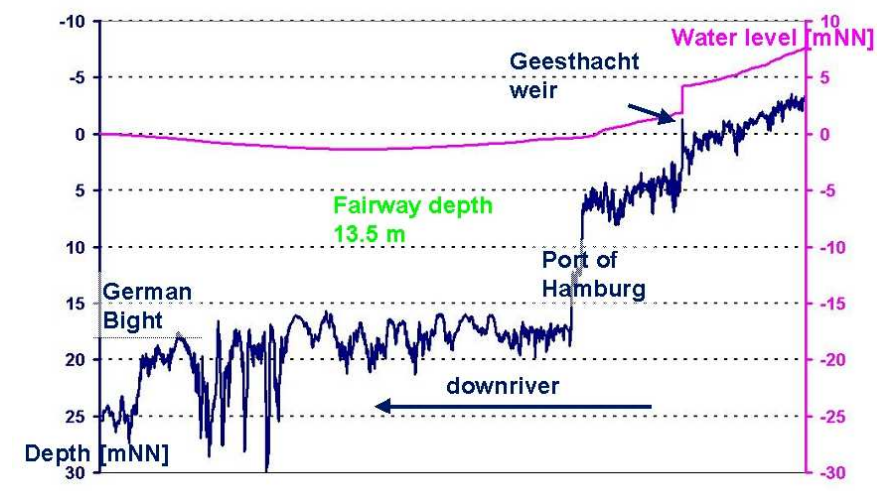

Figure 1. Fairway depth profile between the mouth of the river Elbe and a point $150 \mathrm{~km}$ upriver together with sea level at a certain time

\section{THE PROJECT OPTEL}

The principal objective of the research project OPTEL (Operational Elbe Tidal Estuary Model) is to provide hydrological and oceanographic forecasts about water levels, currents, salinity, temperature and ice conditions for any tidally influenced place on the river Elbe. By using a numerical model, it is ensured that water levels and currents are coupled dynamically, which allows peak water levels, slack water times, and - in 3D modelling - flow profile to be modelled in a physically consistent way and with high resemblance to natural conditions.

Less spectacular events, which are nevertheless relevant to shipping in the tidal estuary of the river Elbe and to the operation of power plants using river water for cooling, are extended periods of extremely low river runoffs in connection with easterly winds in the German Bight. Low water levels may considerably reduce the length of the tidal phase that is suitable for deep-draught vessels entering or leaving port. They may also lead to shorter laytimes in harbour basins, depending on the load condition of ships. A subgoal of the project in this context is the provision of more precise real-time water level data, and thus information about water depths, in the area of Hamburg harbour and downstream.

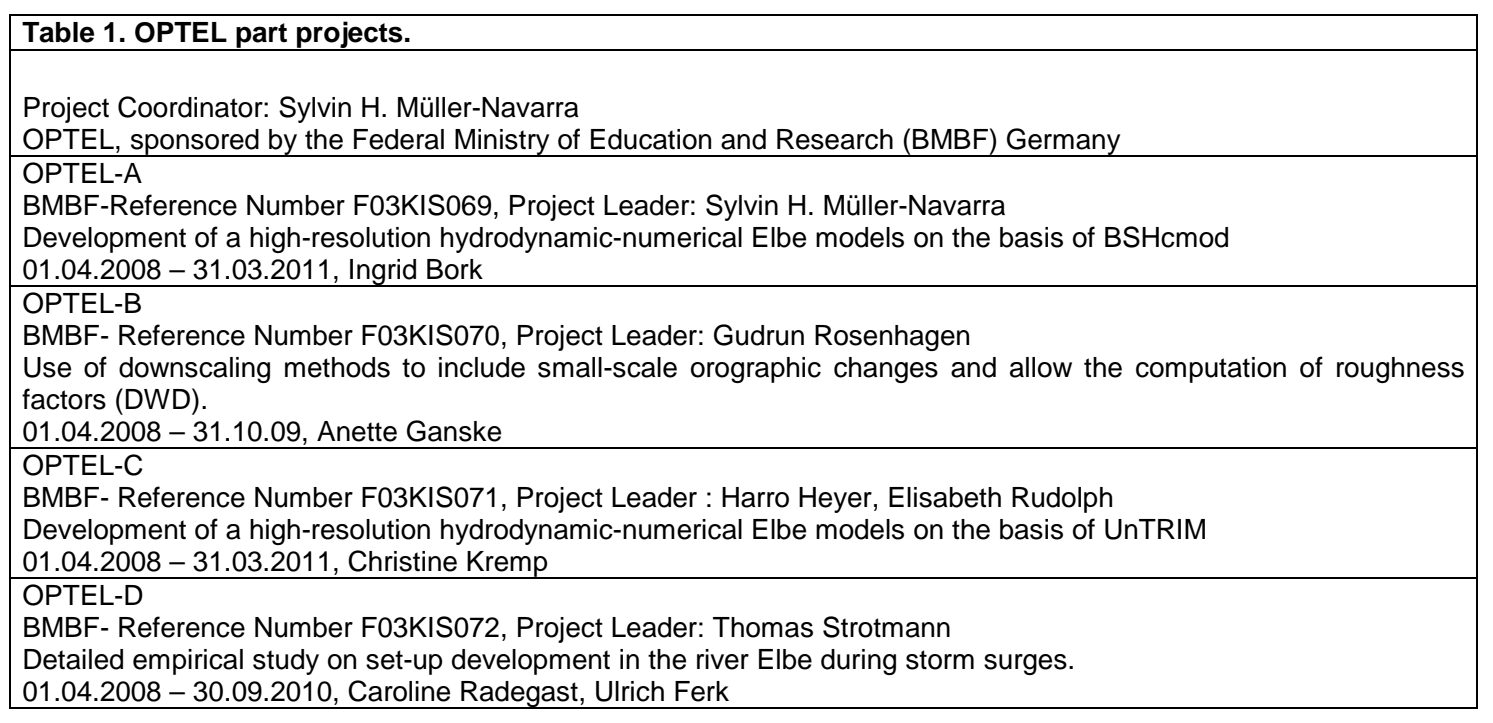

The OPTEL project partners are Federal Waterways Engineering and Research Institute (BAW), Federal Maritime and Hydrographic Agency (BSH), Hamburg Port Authority (HPA), and German Meteorological Service (DWD). The BSH is running an operational model system of the Northeast 
Atlantic, the North Sea and Baltic Sea as part of its statutory tasks in the fields of navigation and hydrography. The system was also used in hindcast studies (Müller-Navarra et al. 2006).

The OPTEL project is divided into 4 part projects (Tab. 1). This paper deals mainly with part project A.

\section{THE NUMERICAL MODEL}

Taking into account existing conditions in the estuary, the requirements to be met by the model are as follows: The model must allow precise water level forecasts and storm surge forecasts to be made for the Lower Elbe. Also simulations of flood waves following extreme rainfall or caused by rapid snow melt in the Elbe drainage area must be possible. The model must provide present and predicted water levels and currents for nautical and other purposes for the entire area of the tidal Elbe river. Additional spatial and temporal parameters to be computed are: Water temperature and salinity. Suitable numerical model systems for this purpose are available, these are UnTrim (Casulli and Walters 2000) and BSHcmod (Dick et al. 2001 and 2008). In the OPTEL project, these methods are integrated into the existing BSH forecast model system of the North Sea and the Baltic Sea.

The modelling chain of the BSH consisting of the Northeast Atlantic model (6 nautical miles), North and Baltic Sea model ( 3 n. m.) and a coastal model $(0.5 \mathrm{n}$. m.), now includes the Elbe model $(0.05$ n. m.). Computation is based on spherical co-ordinates, with grids that are equidistant in Lambda and Phi. Horizontal grid spacing of $90 \mathrm{~m}$ and 8 vertical layers were chosen for the river Elbe. This results in nearly 400,000 volume units.

Special features of the three dimensional numerical model of the BSH are the general vertical coordinates, bi-directional nesting of model areas of different resolution. Other features to be mentioned are the inclusion of direct tides in the model and the fact that the formation of ice and ice drift can be forecast as well. A more detailed description is given in table 2 .

\begin{tabular}{|c|c|c|c|c|}
\hline Model domain & River Elbe & German Bight & $\begin{array}{l}\text { North } \\
\text { Sea/Baltic }\end{array}$ & NE Atlantic \\
\hline Horizontal coordinates & \multicolumn{4}{|l|}{$\varphi, \lambda$} \\
\hline Grid spacing & $\sim 90 \mathrm{~m}$ & $\sim 900 \mathrm{~m}$ & $\sim 5000 \mathrm{~m}$ & $\sim 10000 \mathrm{~m}$ \\
\hline Vertical coordinates & \multicolumn{4}{|l|}{ general } \\
\hline \begin{tabular}{|l|} 
Number of vertical layers \\
\end{tabular} & 7 & 25 & 36 & 1 \\
\hline Number of volume elements & 397157 & 1117390 & 643922 & 26424 \\
\hline \begin{tabular}{|l|} 
Nesting to the outer domain \\
\end{tabular} & $\begin{array}{l}\text { one way (test phase), } \\
\text { bi-directional }\end{array}$ & bi-directional & one way & open boundary \\
\hline Prognostic variables & \multicolumn{3}{|l|}{$\mathrm{v}, \Delta \mathrm{z}, \mathrm{T}, \mathrm{S}, \mathrm{v}_{\text {ice }}, \Delta \mathrm{z}_{\text {ice }}$} & $\mathrm{v}, \Delta \mathrm{z}$ \\
\hline Initial value & test fields & dead start 1992 & & dead start 2008 \\
\hline Tides & \multicolumn{3}{|l|}{ direct + co-oscillating } & none \\
\hline Grid & \multicolumn{4}{|l|}{ Arakawa C } \\
\hline Time integration & \multicolumn{4}{|l|}{ explicit } \\
\hline Exception (implicit) & \multicolumn{3}{|l|}{ vertical exchange } & none \\
\hline Variables at open boundary & \multicolumn{2}{|l|}{ all prognostic } & $\Delta \mathrm{z}, \mathrm{T}, \mathrm{S}$ & radiation $\mathrm{BC}$ \\
\hline River runoff & hourly & \multicolumn{3}{|l|}{ daily } \\
\hline Atmospheric input variables & \multicolumn{3}{|l|}{$\mathrm{V}_{\text {air }(10 \mathrm{~m})}, \mathrm{P}_{\text {air }}, \mathrm{T}_{\text {air }}, \mathrm{q}_{\text {air }}, \mathrm{C}_{\text {air }}$} & $V_{\text {air }(10 \mathrm{~m}),}, p_{\text {air }}$ \\
\hline Drag coefficient & \multicolumn{4}{|l|}{$0.63^{*} 10^{-3}+0.066\left|V_{\text {air }}(10 \mathrm{~m})\right|$} \\
\hline Drag coefficient under ice & \multicolumn{3}{|l|}{ modified by ice } & none \\
\hline Code language & \multicolumn{4}{|l|}{ FORTRAN } \\
\hline System software & \multicolumn{4}{|l|}{ UNIX } \\
\hline
\end{tabular}

The model topography (Fig. 2) was contributed by BAW and was updated with the recent survey data (here: 2006). The wind data used to force the model are obtained from DWD's deterministic numerical weather prediction models and are available at resolutions of $7 \mathrm{~km}$ (COSMO-EU) for periods of 78 hours. For the Elbe model modifications in wind speed and direction due to small scale bottom roughness are provided by OPTEL-B. 




Figure 2. 2006 topography of the model area in $\mathrm{m} \mathrm{NN}$.

\section{FIRST MODEL RESULTS}

During storm surges and high river runoff $\left(>1,200 \mathrm{~m}^{3} / \mathrm{s}\right)$ from the upper reaches of the Elbe into the tidal estuary, the Geesthacht weir (Elbe km 586) is routinely opened. The Elbe model thus covers the area from Bleckede (Elbe km 550) through Hamburg und Cuxhaven (Elbe km 727) to beacons A and Z (Elbe km 756) in the mouth of the river Elbe. Hindcasts of a storm surge and of a period with extreme river runoff will be presented.

The model system additionally including the Elbe model has been operational for just a short time now. Only 3 cases with simulation periods of a few days have been simulated so far. One case describes a situation with calm weather, another one a storm surge, and the third case is a flood wave simulation.

Case 1 - Calm Weather (tidal regime, river runoff $900 \mathrm{~m}^{3} / \mathrm{s}$ )

Case 2 - Storm surge (1.11.2006, river runoff $\left.300 \mathrm{~m}^{3} / \mathrm{s}\right)$

Case 3 - Flood in upper reaches (as case 1, but river runoff $3,500 \mathrm{~m}^{3} / \mathrm{s}$ )

In Figure 3a, the speed of the flood current is shown during calm weather, which means these are essentially tidal currents. As soon as the flow rate exceeds $0.8 \mathrm{~m} / \mathrm{s}$, an arrow of velocity is shown additionally. In comparison flood current during storm surge is shown (Figure 3b). Perhaps unexpected, its speed is less then under calm conditions as the current is opposed by the remains of the previous low water.

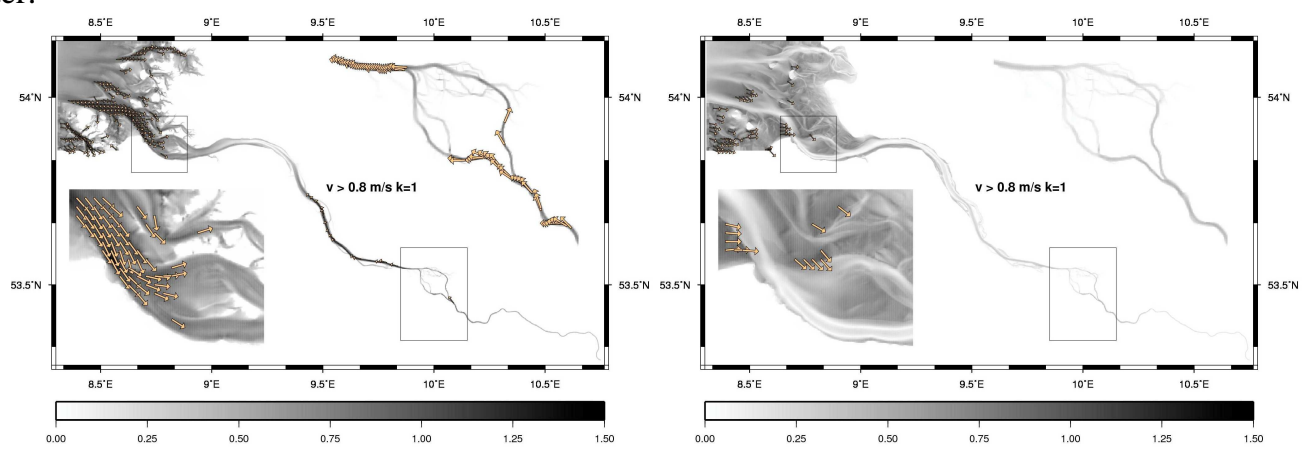

Figure 3 a. Flood current during calm weather (case 1). Figure 3 b. Flood current during storm surge (case 2).

During calm weather as well as during storm surge shown, the pattern of tidal gullies in the estuary is clearly reflected in the current speeds.

Storm surges lead to dramatic changes in the tidal regime, and water level curves may be subject to major deformation. The following figure 4 shows two stages of water level distribution during the storm surge of 2006. Especially, Figure $4 \mathrm{~b}$ shows water passing the weir at Geesthacht from downstream during storm surge. 


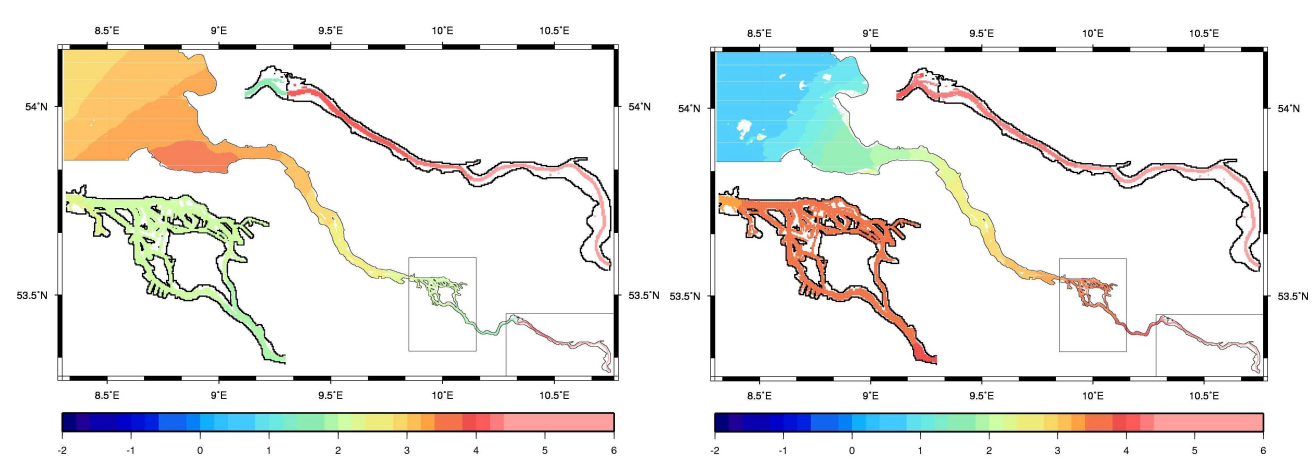

Figure 4. Water level (case 2) in $\mathrm{mNN}$ at time of peak level at Cuxhaven (figure 4a) and of peak level at Geesthacht (figure 4b).

Finally case 3, demonstrating the flow-off of a flood wave with the weir opened, is shown. The first picture shows the water level before opening the weir, with a discharge rate of $900 \mathrm{~m}^{3} / \mathrm{s}$. The second picture shows a discharge rate of $3500 \mathrm{~m}^{3} / \mathrm{s}$ with the weir opened, starting from water level shown in Figure 5a. Downstream of the weir and near Bleckede, the water level rises several meters. The model also produces a realistic simulation of the overflowing of normally dry sections of the river as well as tidal flats.



Figure 5 a. Water level $\mathrm{mNN}$ (case 1) $\left(900 \mathrm{~m}^{3} / \mathrm{s}\right)$. Figure $5 \mathrm{~b}$. Water level $\mathrm{mNN} 9$ hours after switching to 3500 $\mathrm{m}^{3} / \mathrm{s}$ (case 3).

\section{MODEL OUTPUT STATISTICS (MOS)}

BSH's model chain works well with respect to water level forecast (Gästgifars et al. 2008). However, a comparison of forecasts with measurements at specific locations within a model domain shows small systematic errors. By postprocessing the direct model output (DMO) with a appropriate statistical method these errors can be removed significantly. In meteorology model output statistics (MOS) is widely used (Glahn and Lowry 1972), for example for terminal aerodrome forecasts (TAF). At BSH this method is now used for the first time for water level forecasts in tidal waters (Fig. 6). 


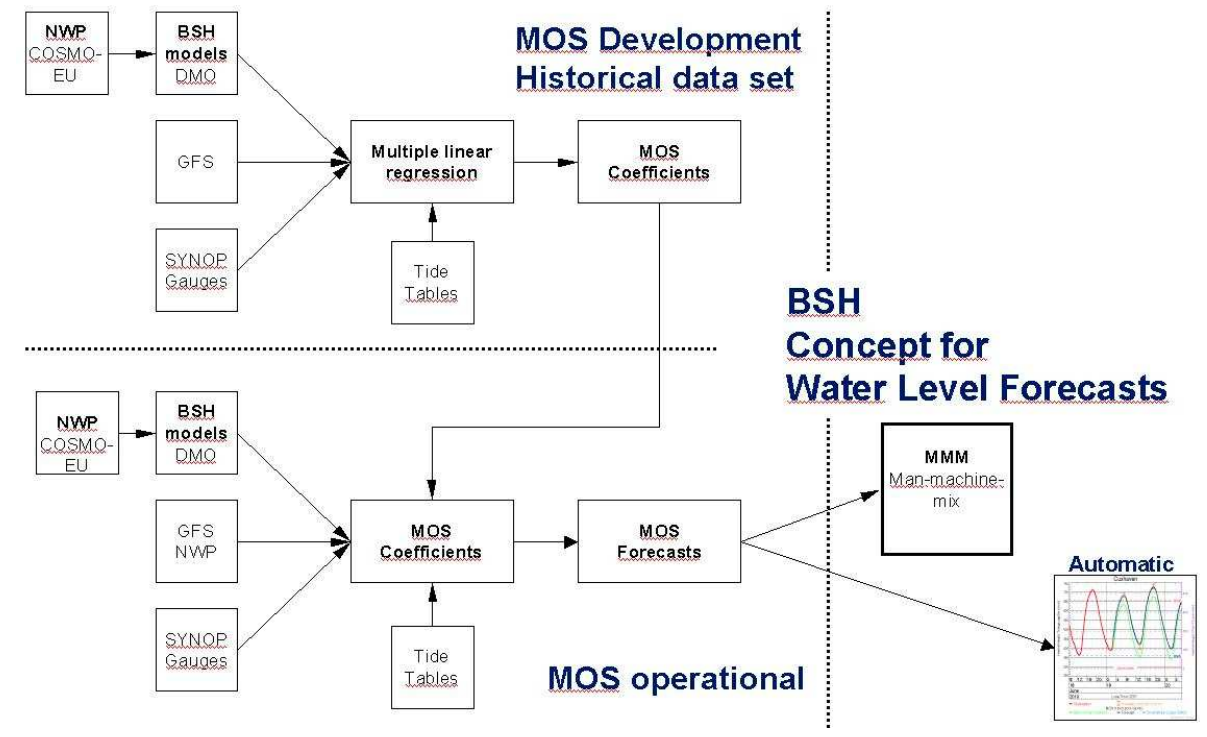

Figure 6. MOS concept for water level forecasts

In this technique, direct model output is linked with suitable predictors from other sources via multiple linear regression, and the MOS equations obtained are used to prepare the forecast. Linkage of the model with current tide gauge data is of special importance in this method (Müller-Navarra and Knüpffer, 2010).

In BSH's water level forecast procedure, MOS has a distinct influence on the final results elaborated by means of a man-machine-mix. Additionally, the forecasts are processed to obtain fully automated products. Overall, by using model output statistics, the RMSE of the forecasts is reduced considerably in forecasting periods of up to about 30 hours.

Figure 7 finally demonstrates how a water level curve at the Cuxhaven gauge in the Elbe estuary can be predicted using MOS, with the latest available data and the numerical model included. The red curve shows the once-a-minute water level measurements, the green curve the astronomical predictions, the blue line the direct model output, and the black curve is the complete MOS forecast. What can be seen clearly is that the DMO during this period is rather dominant, but statistical post-processing using MOS nevertheless is capable of refining the results.

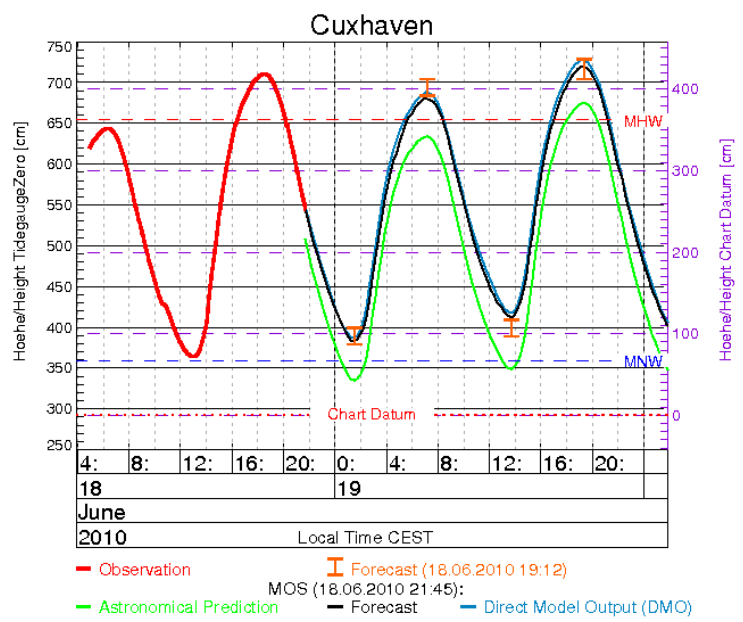

Figure 7. Curve forecast with MOS. The man-machine-mix forecast for high and low water heights are plotted with an orange-coloured symbol indicating an height interval. 


\section{REFERENCES}

Casulli, V. and R. A. Walters. 2000. An unstructed, three - dimensional model based on the shallow water equations, Int. J. for Numerical Methods in Fluids, 32, 331-348.

Dick, S., E. Kleine, S. H. Müller-Navarra, H. Klein and H. Komo. 2001. The Operational Circulation Model of BSH (BSHcmod) - Model description and validation. Berichte des Bundesamtes für Seeschifffahrt und Hydrographie 29, 49 pp.

Dick, S., E. Kleine and F. Janssen. 2008. First Results of a New Operational Circulation Model for the North Sea and the Baltic Using General Vertical Co-ordinates. Proceedings of Euro-GOOS Conference, Exeter.

Gästgifars, M., S. H. Müller-Navarra, L. Funkquist and V. Huess. 2008. Evaluation of operational water level forecasts in the Gulf of Finland, Ocean Dynamics 58, 139-153.

Glahn, H. R. and D. A. Lowry. 1972. The use of model output statistics (MOS) in objective weather forecasting, J. Appl. Meteor. 11, 1203-1211.

Müller-Navarra, S. H., I. Bork, J. Jensen, Ch. Koziar, C. H. Mudersbach, A. Müller and E. Rudolph. 2006. Modellstudien zur Sturmflut und zum Hamburg-Orkan 1962. Hansa 143, 12/06, 72-88.

Müller-Navarra, S. H. and K. Knüpffer. 2010. Improvement of water level forecasts for tidal harbours by means of model output statistics (MOS) - Part I (Skew surge forecast). Berichte des Bundesamtes für Seeschiffahrt und Hydrographie 47 (in press). 